\title{
Improving Early Childhood Language Ability through Scrabble for Kids
}

\author{
Dwi Hastuti \\ Early Childhood Teacher Education, \\ Faculty of Teacher Training and Education \\ Universitas Ahmad Dahlan \\ Yogyakarta, Indonesia \\ d.hastuti28@yahoo.com
}

\begin{abstract}
Language is a very important aspect of early childhood language ability. By language, children may interact with their environment, find something new, and express their ideas. To improve their potential, especially in language, it is important to create a media of teaching which is suitable for kids. Scrabble for Kids is a teaching media which may stimulate early childhood language ability development. This media is the improvement of scrabble well known by public. Scrabble for Kids consists of 60 cubes and a playing board. To adapt with childhood characterization, those cubes are designed to be interesting and colorful with one picture and letters on the sides on each cube. The pictures are of animal, fruits, and other home furnishings. This article is aimed to explain how to use Scrabble for Kids to improve early childhood language ability with fun and is appropriate with learning by playing principles.
\end{abstract}

Keywords-scrabble for kids; language ability; early childhood

\section{INTRODUCTION}

Early childhood education is a starting point in making qualified agent of change in a nation. An attempt to guide and construct good character has been conducted holistically addressing newborn children until they rich the age of six. In fact, early childhood education should be given because children in that period have many characters and potentials to develop. Children are commonly active, dynamic, enthusiastic and curious about what they see and hear. Furthermore, in this period, children are in the most potential time to be given stimuli. In addition, childhood is the most detrimental period to grow character and personality. It is very important for their permanent intelligence because during that period children have strong ability to absorb information.

Indonesian legal law about national education system number 20, 2003 stated that early childhood is an effort to be addressed to newborn children until they reach six years old [1]. Morrison stated that Early Childhood Education (ECE) is the education of children from birth to age eight [2]. In this period, children are very active as they have strong couriosity. ECE is also known as golden age because during this period developmental process has reached its fastest progress and it is the fastest in the human's entire lifetime. Children can reach
$80 \%$ of brain development from all of their ability. Their developmental characters are holistic covering all aspects.

In this golden age, education plays a very fundamental role to determine children's future development. If children are given good stimuli, then all developmental aspects will be maximally developed. Thus, ECE should trigger all important aspects such as religion, moral, social, emotional, cognitive, language, and phsycal motoric. This process should be done in a various and creative learning method for children. It is because growth and development are very important and detrimental for children's future development.

In regard to children's developmental aspect, language aspect is one of the most important. As a social being in a community, language has an important role in social interaction. Language ability must be developed as early as possible. Children should be able to use language as a communication tool because it can help children to adjust with their surrounding environment. It is in line with what Suhartono outlined. He stated that language has an important role for human's life [3]. Language is the main form of expressing thought and knowledge. A growing children can communicate their needs, thought and feeling by using language and meaningful words.

Learning method and media are very important for children's language ability development. Learning media can be used as tool of delivering messages during teaching and learning process. It is because children are in the stage of thinking concrete thing. Learning media or educative learning tool, will help children to learn and understand something new. Children often have to deal with concrete thing where they can interact with all of their sensory. Among those popular methods, singing, telling story, role play and Q\&A are the most used method to develop children's language ability. However, using learning media is not simply enough. Teacher often uses student's worksheet in teaching and learning process which make the activity limited and boring. This limited activity then leads to underdeveloped language ability in children. It does not allow children to express their opinion or argument. Thus, it does not meet the target.

According to the above explanation, the development of children's language ability should be done in more concrete and interesting ways. It should also involve children's sensory. 
Scrabble is one of educative games that can be used to improve children's language ability. Yusep Nurjatmika in Nadya et al. stated that scrabble is a kind of game to arrange words that can be played by two to four person [4] . Players are given some characters, then by those characters players should construct words. Scrabble in this case, is the development of the current scrabble that is well known as Scrabble for Kids. This media is specifically developed for early children. It is designed with an interesting package, colorful, and picture rich. This learning media consists of written small cube and its playing board.

This paper aims at conceptually discussing how the development of children's language ability can be done in more interesting ways. It also aims at adjusting the game with the characteristics of every child. Scrabble for kids is an educative learning media that can stimulate joyful learning so that children can improve their language ability more fun.

\section{LANGUAGE ABILITY}

\section{A. The Definition of Language}

Language is a vital aspect in social life. Language can help someone to communicate and interact with other people in daily basis. According to Stice, Bertrand and Bertrand (1995) in (Otto, 2015: 3), language is a systematic symbol that categorizes, organizes and clarifies our mind [5].

Similarly, Susanto (2011:74) stated that language is a tool to think, express and communicate [6]. Language ability is also important in creating concept, information and problem solving. Language allows people to understand feelings and minds. Children can find many things in their environment by using language. Based on the above definition, language is a communication tool that is used from sound, word, pattern that human used to tell and express their feeling and thought.

\section{B. Language Mastery}

Communication becomes the basic need for every child because they are social beings that must be lived in a community. Therefore, language mastery for children should be developed since the very young age as the basic tool for them to learn and adjust to new people or new environment. Language also becomes indicator of success to children. Commonly, children who are talkative and able to express their opinion is indicated as a smart child.

Language mastery consists of four main aspects. They are listening, speaking, reading and writing. Below, there will be an explanation on how to create good environment for children's language mastery.

\section{- Listening}

Children's language ability develops in both receptive and expressive aspect. Wolvin and Coakley (1985) argued that listening is a kind of important receptive skil. Listening can help people to accept language and it is not a passive activity. Listening can be effective is it is done actively with purpose [5].
Ability to listen correctly and accurately are important criterion in learning and communicating. It is very important in the beginning stage of language learning. To improve children's listening ability, parent or teacher can be a model for children to communicate, inform and encourage activity that is closely related to listening skill. There are some activities that can be done. They are (a) playing and listening to music, (b) telling story (c) listening to many sounds, (d) listening to music story and (e) questioning to what they heard.

\section{- Speaking}

Generally, speaking is an activity to tell and deliver messages (idea, thought, argument or feeling) to somebody else orally so that people can understand.

Speaking ability should be trained since the young age and it can be conducted with the help of other people in a conversation. By having a conversation, children will find many experience, increase their understanding and develop their language. Parent can allocate some times to have short conversation with children in order to shape their language ability, encourage them to express opinion, asking question and making decision. Parent, in addition can train children to have concise, clear and correct language to speak. They can also use gesture or mimic.

\section{- Reading}

Reading also becomes an important skill for children. Having reading as a hobby can allow children to have high language sense. Montessori stated that children are ready to be taught to read and write in the age of 4-5 years old. Indeed, the teaching and learning process should be conducted in a fund method like games.

Children should be encouraged to have reading habit since the very first place. It may take a very long process starting from understanding symbol to sentence. Parent can teach them to increase vocabularies before reading.

\section{- Writing}

To start teaching writing, parent or teacher must pay attention on children's readiness. This skill can be taught if children's soft motoric is ready enough. It can be seen from their ability to hold pencils. In the beginning, children hold pencils to draw randomly but as it developed, they are able to concentrate their fingers to write smoothly. Writing ability is closely related to drawing ability because they both require psychomotor and cognitive ability. By writing or drawing, children can express themselves. It is when parent or teacher can introduce the power of drawing and writing they can create. 


\section{The Purpose of Language Development for Children}

In general, the purpose of language development for children is to make them able to express their feeling (argumeny, idea) orally. According to Suhartono, there are general purpose of language development, they are (1) Having enough vocabulary, (2) Having willingness to listen and understand words and sentences, (3) Having ability to express argument and stance correctly, (4) Passionate to use correct language, (5) Passionate to connect oral and written language [3].

\section{Language Characteristics for Children}

According to Permendiknas no. 58, 2009 passing grades is arranged based on age group [7]. Level of achievement reflects the growth and development of children that is expected to be achieved in particular time. Below is the table of children's language development based on Child Development Institute (2006) as well as the passing grade of children's language based on Permendiknas Number 28, 2009.

Table 1. Children Development in General according to Child Development Institute (2010:6.3)

\begin{tabular}{|l|l|}
\hline Age & Children's Language Development \\
\hline 5- 6 Years & $\begin{array}{l}\text { In this period, children are able to make } \\
\text { clear conversation so that other could } \\
\text { understand the main point. Getting better } \\
\text { in spelling and processing words, able to } \\
\text { follow plot of a story as well as } \\
\text { memorizing ideas and information in a } \\
\text { book. They start to love poem, games and } \\
\text { comedy using some incorrect sentence. } \\
\text { They have at least 1500 vocabularies } \\
\text { where they can tell stories using complex } \\
\text { sentence. }\end{array}$ \\
\hline
\end{tabular}

The Table 2 informs the development of language's children ability in the age of 5-6 years old. There are some important aspect such as accepting language, understanding command all together, repeating more complex sentence in a story, understanding rules in school or home.

\section{MEDIA SCRABBLE FOR KIDS}

\section{A. The Definition of Media}

Media is originated from Latin word "medius" which means middle, mediator or person who bridge the gap between others. In Arabic, media means message delivery from one to another [8]. According to Gerlach and Ely media is human, material and phenomenon that allow student to get knowledge, skill and stance [8]. Thus, media can be teacher, textbook and environment which can be used to help student to learn. Media can be everything to be used to send message from one to another so that it can trigger thought, feeling, attention and passion for student to learn.
Table 2. Level of achievement of children's language development based on age group in Permendiknas no. 58, 2009 : 5-6 years old

\begin{tabular}{|c|c|}
\hline $\begin{array}{l}\text { Development } \\
\text { Coverage }\end{array}$ & $\begin{array}{l}\text { Level of achievement and } \\
\text { development }\end{array}$ \\
\hline $\begin{array}{l}\text { a. Accepting } \\
\text { Language }\end{array}$ & $\begin{array}{l}>\text { Observing other's talk (Mother } \\
\text { tounge or other language) } \\
>\quad \text { Understanding command that is } \\
\text { given altogether } \\
>\quad \text { Understanding stories that is } \\
\text { recited } \\
>\quad \text { Knowing vocabularies about } \\
\text { adjective (naughty, kind, } \\
\text { brave, good, bad, etc) } \\
>\text { Understanding command } \\
>\text { Repeating more complex } \\
>\text { sentence Understanding rules in a game }\end{array}$ \\
\hline $\begin{array}{l}\text { b.Expressing } \\
\text { Language }\end{array}$ & 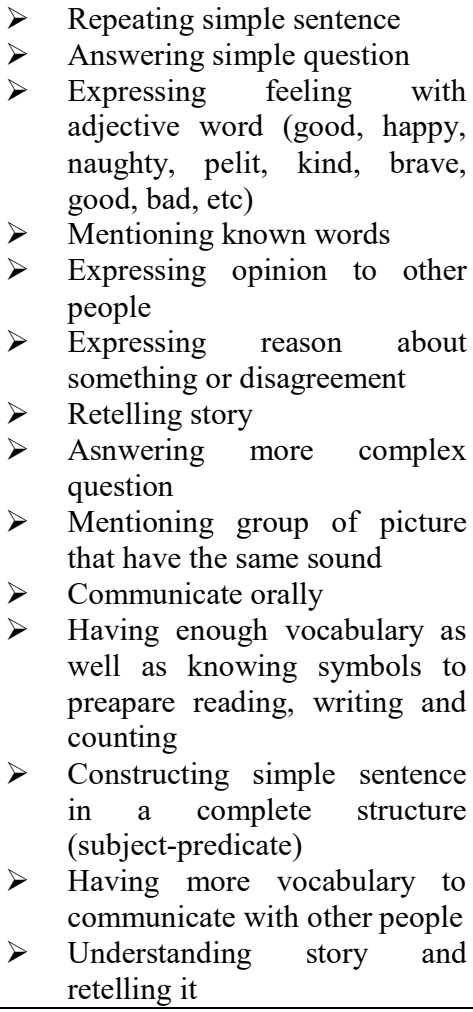 \\
\hline c. Literacy & $\begin{array}{l}> \\
>\end{array} \begin{array}{l}\text { Knowing symbols } \\
\text { Knowing animal's sound or } \\
\text { thing in surrounding } \\
\text { environment } \\
>\quad \text { Making meaningful random } \\
\text { writing } \\
>\text { Copying words } \\
>\text { Mentioning alphabet symbols } \\
\text { Knowing word's sound from } \\
\text { their surrounding } \\
>\quad \text { Mentioning group of picture } \\
\text { that has sound the relation } \\
>\text { Understanding the } \\
\text { between sound and thing } \\
>\text { Mentioning their own name } \\
\text { Writing their own name }\end{array}$ \\
\hline
\end{tabular}




\section{B. The Definition of Scrabble}

Scrabble is a kind of board game that is used by school as a curricular to support academic activity. Scrabble is commonly used to develop language skill [9]. Pratt stated that scrabble is a game that can be played by two to four players [10]. This game aims at arranging alphabet to be meaningful words in a designed box. It has 15 rows and 15 coloums with 100 tiles. This game is quite similar to jumble words because players should construct the word horizontally or vertically.

Basically, this game is played with constructing alphabet into words. Thus children must remember vocabularies in order to finish the game. Scrabble is categorized as an educative game because it is constructive. Besides, scrabble that consists of letters can help children to identify characters or to arrange words. It can stimulate children to develop their language ability. Hinebaugh (2009) stated that scrabble as an educative game has some advantages. They are (1) It can increase reading ability, (2) It can develop vocabulary, (3) It can increase grammar ability, (4) It can train spelling correctness [9].

\section{The Definition of Scrabble for Kids}

Scrabble for kids is a kind of educative game that has been developed from Scrabble media. The development is to specify the use of media which is for children. Scrabble for kids consists of board and 60 pieces of small cube. Every side of the cube has been designed with different colors. From 6 side, five of them has one letters while the rest side has picture in it. They are the picture of fruits, animals and other common things.

\section{Kinds of Games in Scrabble for Kids}

There are some types of game in this scrabble for kids. The choice of type has been adjusted with the age and development of children. Below are the detail type of the game.

\section{- Colors Construction}

This is the simplest game among others. Children will arrange the colorful cubes vertically and horizontally based on its color. The cube is painted the same in each. There are different colors such as red, yellow, green, blue and violet. The player can win the game if they are able to arrange the cube in the same color. Teacher or parent can ask some question like their hobby, or similar color while children are playing.

\section{- Constructing Form}

This game aims at constructing cubes into something like ship, animal, flowers and other. Children can do it as they wish for with colorful cubes. After that, children can tell the story behind the that.

\section{- Picture Classification}

One of side in cube has picture in it. There are animal, fruits and other things. Children are asked to classified the picture based in its type. For instance, animal can be classified based on the number of leg, habitat and kind of food it ate.

\section{- Making Tower}

Making tower is a game that can help children to be concentrating, careful and patient. Children will try to construct the cube as high as possible. Slowly, they will start it one by one to make a tower. During this stage, children will be trained to concentrate and careful in order to finish the game.

- Guessing Picture

Guessing picture is a game that can be played by children. They will be asked to put on a picture and guess what kind of picture was that. Then children must construct a word about the picture. They will find required letters and construct it accordingly.

- Jumble Words

This game should be played by more than one player. They will take turn to construct the words in a box. Then the word must be like in a jumble words game. It cross one another but still meaningful.

\section{IMPROVING CHILDREN LANGUAGE ABILITY USING SCRABBLE FOR KIDS}

Scrabble for kids is an alternative design of game that aims at improving children's language ability. This media can help children learn by using games. As explained above, scrabble for kids has some types of game that can be played. They are colors construction, constructing form, picture classification, making tower, guessing picture, and jumble words. When children train to construct color, they will be introduced to kinds of color and grouped them based on the group of color. Furthermore, they will be able to mention kinds of thing with its color that has similar color with the cubes. Children's ability in arranging alphabet to be word can be trained with guessing picture. Children will identify the picture provided, then they will be asked to find some letters that represent the picture and try to make a word.

Jumble word, in addition can stimulate children to learn new vocabularies. Jumble word is an advanced level of scrabble for kids. Children will be asked to arrange word both vertically of horizontally in a scrabble board. Words should be jumbled and crossing each other. Moreover, this game requires and trains children not only to enrich their vocabulary but also help them to make strategy.

Scrabble can train children to have constructive mind where they arrange the words. They will know alphabet as well as knowing words and its spelling. Language ability will be developed when children are able to express verbally.

\section{CONCLUSION}

In conclusion, scrabble for kids can be one of the alternative media to develop children language ability. The colorful design that is equipped with pictures allows more interest and passion to come. They are triggered to participate 
actively. In addition, the variety of the games will give them more chance to improve their language ability more fun.

This paper, however is still in a conceptual form. It requires more research to develop the game. By involving more experts and practitioners, this game will be improving better. They will be able to provide more information quantitatively and qualitatively about the scrabble in developing children's language ability.

\section{References}

[1] Sugiyono. (2003). UU RI No. 20 Tahun 2003 tentang Sistem Pendidikan Nasional. Jakarta: Sinar Grafika.

[2] Morisson, George S. (1988). Education and Development of Infat, Toddlers, and Preschoolers. London: Scoot, Foresman, and Company

[3] Suhartono. (2005). Pengembangan Ketrampilan Berbicara Anak Usia Dini. Jakarta: Depdiknas

[4] Nadya dkk. (2013). Efektifitas Permainan Scrabble dalam Meningkatkan Kemampuan Membaca Permulaan Bagi Anak Kesulitan Membaca

[5] Otto, Beverly. (2015). Perkembangan Bahasa pada Anak Usia Dini. Jakarta: Kencana

[6] Suyanto, Slamet,. (2005). Pembelajaran untuk Anak TK. Jakarta: Departemen Pendidikan Nasional Direktorat Pembinaan Tenaga Pendidikan

[7] Permendiknas no. 58, 2009

[8]. Arsyad, Azhar. (2011). Media Pembelajaran. Jakarta: Rajawali Pers

[9] Hinebaugh, J.P. (2009). A Boad Game Education. United State America: Rowman \& Littlefield Education.

[10] Varia dkk. (2013). Pengaruh Permainan Scrabble Terhadap Peningkatan Kemampuan Membaca Anak Disleksia 